\title{
INCONSTITUCIONALIDADE MATERIAL DA CONFISSÃO NO ACORDO DE NÃO PERSECUÇÃO PENAL
}

MATERIAL UNCONSTITUTIONALITY

OF CONFESSION IN THE CRIMINAL NON-PERSECUTION AGREEMENT

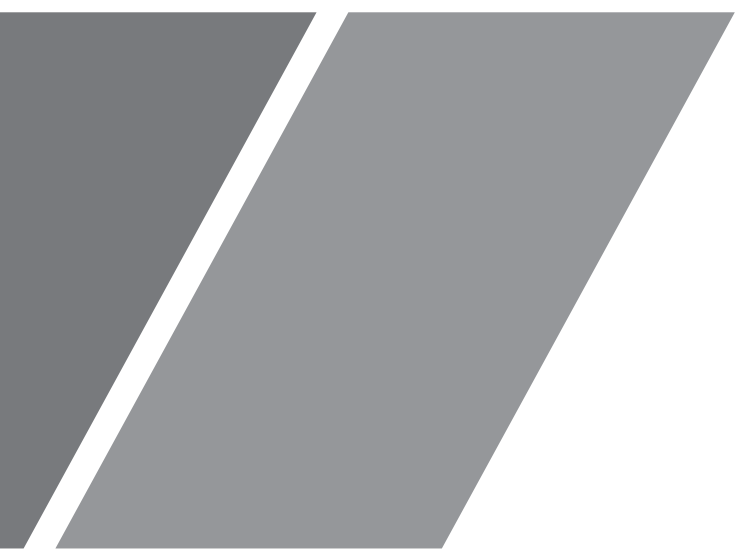




\title{
INCONSTITUCIONALIDADE MATERIAL DA CONFISSÃO NO ACORDO DE NÃO PERSECUÇÃO PENAL ${ }^{1}$
}

\author{
MATERIAL UNCONSTITUTIONALITY OF CONFESSION IN THE CRIMINAL \\ NON-PERSECUTION AGREEMENT
}

\author{
José Carlos Félix da Silva \\ Debora Cristyna Ferreira Reis ${ }^{3}$ \\ Klinsmann Alison Rodrigues Félix da Silva ${ }^{4}$
}

\section{RESUMO}

O acordo de não persecução penal foi introduzido no código de processo penal através da lei 13.964/19, com o intuito de aprimorar a justiça negociada e favorecer o atendimento das demandas a fim gerar punição mais efetiva. Contudo, uma problemática tomou voz, sendo ela a confissão como requisito à celebração do acordo entre Ministério Público e acusado, o que denota inconstitucionalidade para tanto, tendo em vista a sua notória desnecessidade, angariando eventual vantagem ao parquet em possível instauração da ação penal. Partindo do método bibliográfico e documental, o presente trabalho irá apresentar como ocorre a inconstitucionalidade material da confissão, partindo da análise da evolução histórica do processo penal à inserção do acordo no âmbito jurídico brasileiro, a fim de demonstrar o vício no requisito da confissão. Então, embora seja instituto inovador, a discussão é válida, tendo em vista que ocasionará efeitos jurídicos práticos ao longo do tempo.

Palavras-chave: Confissão. Ministério Público. Acordo de Não Persecução Penal. Justiça Consensual.

1 Data de Recebimento: 08/10/2020. Data de Aceite: 23/11/2020.

2 José Carlos Félix da Silva, Promotor de Justiça do Estado do Ceará e professor no curso de Direito da Universidade Regional do Cariri, graduado pela Universidade Federal do Ceará, especialista em Direito Penal e Criminologia. E-mail: mrkharal@gmail.com. Currículo Lattes: http://lattes.cnpq.br/7175640017301800. ORCID: https://orcid.org/0000-00025712-8684. E-mail: mrkharal@gmail.com.

3 Debora Cristyna Ferreira Reis. Estagiária da Secretaria Judiciária de $1^{\circ}$ Grau do Crajubar. Graduanda em Direito pelo Centro Universitário Paraíso. E-mail: debora-cristina1945@hotmail.com. Currículo Lattes: http://lattes.cnpq. br/9803551593677886. ORCID: https://orcid.org/0000-0003-3939-0029. E-mail: debora-cristina1945@hotmail.com. 4 Klinsmann Alison Rodrigues Félix da Silva. Advogado inscrito na OAB/CE 44.110. Graduado em Direito pelo Centro Universitário Paraíso. E-mail: klinsmannfelixx@gmail.com. Currículo Lattes: http://lattes.cnpq.br/5432647978793789. ORCID: https://orcid.org/0000-0002-3017-9385. 


\section{INTRODUÇÃO}

O Pacote Anticrime, visualizado a partir da lei 13.964/19, trouxe em seu bojo a possibilidade do Ministério Público oferecer acordo de não persecução penal, negócio jurídico bilateral e formal, sofrendo posterior ratificação pelo magistrado. Em seu corpo legal, o requisito da confissão vem denotando incômodo e possível prejuízo ao acusado, vez que empodera a acusação, a partir da obtenção da vantagem, por procedimento que não seja o tradicional devido processo legal. Assim, o instituto inovador tem por base uma problemática que direciona o requisito da confissão à inconstitucionalidade material.

O princípio da presunção da inocência, constitucionalmente previsto, estabelece que a culpa do indivíduo somente poderá ser decretada, após transitada em julgado a sentença penal condenatória, pois resguarda a segurança jurídica, não só para o indiciado, e futuro réu, mas também, para a população como um todo, pois impede arbitrariedade estatal, permitindo o contraditório e a ampla defesa, bem como a colheita de provas pelos métodos coerentes e lícitos.

Neste diapasão, é que o acordo não persecutório se insere, prejudicando o direito ao acusado de ser considerado definitivamente culpado, somente após sentença definitiva, se comprometendo com tal requisito com a finalidade de angariar benefícios por parte do Estado, como a não taxação para fins de antecedentes criminais. Denota-se, no entanto, a compulsoriedade em aceitar o negócio, por parte do acusado, possuindo por vantagem a legalidade e a voluntariedade em aceitar a proposta, já formulada, sem que seja pactuada em todos os seus termos.

Partindo do método bibliográfico e documental, com tendência a livros doutrinários e artigos para embasamento do tema, além da pormenorização feita com a busca do método qualitativo, a fim de formar conceito e crítica a respeito da confissão, em sua forma inconstitucional, o presente trabalho aborda a vertente histórica-descritiva, apresentando a evolução do direito penal às medidas alternativas da pena, concentrando-se, ao final, no acordo de não persecução penal.

O tema é de suma relevância para aflorar debates acerca do negócio jurídico implementado no código de processo penal, em seu artigo 28-A, possibilitando análise de sua futura repercussão jurídica, acrescendo aos conceitos da comunidade acadêmica com conteúdo inovador e atual. Objetivando, ainda, demonstrar a inconstitucionalidade material da confissão, da maneira em que ocorre e analisá-la no sistema penal vigente, além de apresentar as mutações sofridas pela persecução penal no Brasil. 


\section{A EVOLUÇÃo DO PROCESSO PENAL ÀS MEDIDAS ALTERNATIVAS DA PENA}

A pretensão punitiva do Estado decorre da ação delituosa ocasionada por pessoas que violam as leis penais existentes, doravante há a transformação do direito de punir em abstrato para o ius puniendi in concreto. A pretensão do Estado em ver punir os infratores, por si só, demonstra insuficiência para resolução do conflito, pois é fundamental a aplicação de uma punição ao criminoso, assim como deve haver todo um procedimento para a sua aplicação, sendo impossível a imposição da pena de maneira arbitrária, como explica Lima (2017, p.37) "Apesar do Estado ser titular do direito de punir, não se admite a imposição imediata da sanção sem que haja um processo regular, assegurando-se, assim, a aplicação da lei penal ao caso concreto, consoante as formalidades prescritas em lei, e sempre por meio dos órgãos jurisdicionais". O processo penal será o instrumento estatal para haver a punição da maneira mais adequada ao criminoso, sempre possuindo como pilar a Constituição, fazendo valer o Estado Democrático de Direito e uma clara distinção entre a democracia e o autoritarismo.

Tendo em vista esse impasse existente entre o ius puniendi estatal e os direitos fundamentais, no momento da aplicação das sanções sobre os indivíduos, faz-se mister a compreensão da estrutura da persecução penal brasileira para detectar, no ordenamento jurídico criminal, onde se insere o acordo celebrado entre Ministério Público e o indiciado. Diante do exposto é válido ressaltar a existência de três sistemas que norteiam o processo penal: o inquisitorial, acusatório e o francês, também conhecido por misto (adotado pelo Brasil).

O primeiro sistema, o inquisitorial, é caracterizado pela inexistência do contraditório e de ampla defesa, concentrando na mão de uma única pessoa, conhecido como juiz inquisidor, o poder de acusar, defender e julgar. Foi adotado pelo direito canônico a partir do Século XIII e posteriormente foi amplamente aderido pelo continente Europeu ficando bem explícito seu funcionamento pela Inquisição, prática que consistia na acusação e julgamento pela Igreja Católica de pessoas taxadas como hereges. É evidente a violação da imparcialidade na figura do juiz inquisidor, pois atua em diversos polos, inclusive opostos, no qual cairá sobre sua responsabilidade, denotando a inegável confusão existente na ação de acusar e simultaneamente decidir sobre a culpa do acusado, uma vez que o acusador fica iníquo ao seu resultado.

O processo inquisitório confere ao juiz amplos poderes probatórios, com o intuito de encontrar uma verdade absoluta, por isso tamanho poder concedido, uma vez que pouco importa como ocorrerá a obtenção da prova e em qual momento deverá ser invocada, pois o acusado é um mero objeto processual, não possuindo direito algum. Embasado 
nesse pensamento, era admitida a tortura do infrator como meio de obtenção da verdade real, Lima (2017, p. 39) afirma que "A gestão das provas estava concentrada, assim, nas mãos do juiz, que, a partir da prova do fato e tomando como parâmetro a lei, podia chegar à conclusão que desejasse".

A fundamentação para a arbitrariedade estatal era a efetividade da justiça, vez que se dava de maneira rápida e garantia segurança para a sociedade, pois o suposto delinquente era isolado, preso, somado ao fato de, como era negada a sua participação no curso processual, não haver maneira de sair impune ao delito cometido, ou supostamente cometido, tendo em vista que em muitos casos haviam condenações duvidosas, proferidas mediante o uso de provas obscuras. Nestor Távora (2019, p.55) explica:

O réu, mero figurante, submete-se ao processo numa condição de absoluta sujeição, sendo em verdade mais um objeto de persecução do que sujeito de direitos. É que, conforme esse sistema, os direitos de um indivíduo não podem se sobrepor ao interesse maior, o coletivo.

O segundo sistema persecutório denomina-se acusatório, distinguindo-se do anterior por possibilitar a desconcentração do poder de acusar, defender e julgar, ou seja, há divisão de funções entre partes distintas, garantindo assim igualdade e, consequentemente, imparcialidade, possuindo como base o princípio da ampla defesa e da publicidade. Se caracteriza por ser oral e público, além de garantir ao acusado a presunção da inocência que, diferentemente do inquisitorial, garante a liberdade durante todo o processo, em regra. A separação das funções processuais fez com que a obtenção das provas exclusivamente e abusivamente pelo magistrado fosse afastada. No referido sistema prevalece a produção de provas pelas partes de maneira igualitária, ficando a cargo do juiz garantir os direitos e liberdades fundamentais, e mesmo que o magistrado possa intervir, no ato da instrução, às partes cabe o encargo das provas:

\footnotetext{
Ainda que se admita que o juiz tenha poderes instrutórios, essa iniciativa deve ser possível apenas no curso do processo, em caráter excepcional, como atividade subsidiária da atuação das partes (LIMA, 2017, p. 40).
}

O último sistema de persecução penal é o francês, ou misto, possuindo duas fases distintas. A primeira fase, denominada pré-processual, é inquisitorial, contudo, não ocorre de forma pura, tendo por único objetivo a apuração da autoria delitiva, sendo um 
procedimento sigiloso e sem a possibilidade da ampla defesa (podendo, no entanto, ser monitorado por defesa técnica instituída pelo acusado), como ocorre, por exemplo, no Inquérito Policial. A segunda fase, a processual, tem caráter acusatório, pois ocorrerá a acusação perante o juiz o qual deve garantir a defesa do acusado para proferir uma decisão sobre o caso, com respeito ao devido processo legal, bem como ao contraditório e a ampla defesa. Notória também é a distinção entre o órgão que acusa e o que julga, bem como a oportunidade à defesa técnica do acusado, o que favorece a imparcialidade. Vale dizer que o sistema penal adotado pelo Brasil é o misto, e o sistema adotado em seu respectivo processo penal é o acusatório, expresso na Constituição Federal, em seu artigo 129, inciso I, delegando ao Ministério Público a titularidade da ação penal pública e conferindo ao juiz o gerenciamento do processo penal impedindo atitudes prejudiciais aos atuantes processuais.

Nesse diapasão é que se inclui o ANPP, tendo em vista as características do acordo em estudo, sendo a aceitação das propostas e a confissão um meio de alternativa a denúncia e posteriormente o cumprimento da pena, outorgado pelo promotor de justiça, fica evidente a origem de um novo sistema, pois não há a figura de juiz inquisidor e tampouco o oferecimento da denúncia. Assim, encerrada a fase inquisitorial, o Ministério Público poderá dispor da ação em face da justiça consensual, oferecendo acordo de não persecução, evitando o início de um processo, por vezes, moroso, e poupando gastos, tendo em vista a possibilidade do acusado ser, após todo o tramite processual, posto em liberdade, quando por meio de negócio jurídico, tal situação ocorreria antes mesmo de ser movimentado o tradicional rito processual, com consequente desgaste econômico.

O progresso do sistema penal pode ser analisado sobre várias perspectivas, possuindo como ponto primordial a inovação e adaptação conforme a sua necessidade. Cunha (2020) traz consigo uma perspectiva diferente sobre essa evolução, analisando sob o aspecto de cinco velocidades, baseadas nas ideias de Jésus-Maria Silva Sánchez, contida em sua obra denominada "La Expansión del Derecho Penal".

A autora define como a primeira velocidade do Direito Penal, o cárcere, portanto, a pena é a última medida a ser aplicada, quando adentrada em seara criminal, sendo ela a regra dotada pelo Brasil, considerando que a justiça negociada ainda está sendo formada. A segunda velocidade apresenta-se essencialmente contrária à anterior, tendo em vista que estabelece medidas alternativas à pena privativa de liberdade, no Brasil pode ser verificada a partir da lei 9.099/95, conhecida por ser a Lei dos Juizados Especiais, através dos institutos da transação penal e suspensão condicional do processo.

A terceira velocidade possui como norte o direito penal do inimigo, teoria criada por Günther Jakobs, distinguindo o cidadão do infrator, este não sendo sujeito de direitos podendo ser vítima de métodos cruéis para a obtenção da verdade como a tortura. Possui 
aplicabilidade conferida na lei do abate, lei 9.614/98, que permite a derrubada de aeronaves desconhecidas no espaço aéreo brasileiro. Considerada híbrida, por possuir duas vertentes, a primeira que visa como último fim a pena de prisão, decorrente da primeira velocidade, e a segunda vertente prevendo o afastamento de determinadas garantias penais e processuais do indivíduo, extraída da segunda velocidade.

A quarta velocidade é conhecida como neopunitivismo que é caracterizado pela prática de um sistema penal de um Estado sobre o outro, ou seja, ocorre um julgamento de um determinado país, a partir do embasamento legal e normativo de outro país, ou grupo de países, uma evidente violação da soberania. Tal prática foi perceptível no julgamento da Alemanha Nazista perante o Tribunal Internacional de Nuremberg, pelos países vitoriosos da Segunda Guerra Mundial.

Por fim, a quinta e última velocidade, tem seu foco na coletividade na qual não se deve analisar o individual, devendo ser ultrapassada a esfera do particular para abranger bens jurídicos transindividuais e possuir um olhar mais amplo, como a proteção ao meio ambiente. Tal ideia foi criada pelo professor penalista Günter Stratenwerth, podendo ser observado a aplicação dessa ideia no ordenamento brasileiro com a lei 9.605/98 que preserva o meio ambiente e a lei 8.069/90 que criou o Estatuto da Criança e do Adolescente.

Visto isso, enquadra-se, o acordo de não persecução, nos anseios da segunda velocidade do direito penal, por ser método nitidamente despenalizante e ocasionar cessão de direitos por parte do acusado, entretanto, tal cessão não pode ser explanada como anor-

mal, dada a característica da justiça consensual ceder direitos frente a outros direitos, como forma de ponderação e negociação, visando algo maior e mais benéfico.

\section{A LegalizaÇÃo do ACORdo de não PeRSECUÇÃo PENAL No SISTEMA JURÍDICO BRASILEIRO}

A constitucionalização do Acordo de Não Persecução Penal (ANPP) se deu através da lei 13.964/19, intitulada de Pacote Anticrime, que em seu artigo $3^{\circ}$ atribuiu ao Código de Processo Penal (CPP) o artigo 28-A que disciplina toda a matéria de não persecução em âmbito pré-processual penal. Antes o referido instituto era regulamentado pelas Resoluções 181/2017 e 183/2018, ambas do Conselho Nacional do Ministério Público (CNMP), o que gerava sérias discussões quanto à sua aplicação, tendo em vista a ausência de amparo legal para dar suporte e reger a matéria procedimental.

O Pacote Anticrime foi concebido diante da crescente impunidade dos agentes delituosos por consequência de vários motivos, inclusive por serem agraciados pela prescrição decorrente da demora em processar e julgar os casos. Assim, a realização do 
ANPP, demonstra uma possível redução dos problemas que cercam o Poder Judiciário, enxugando as demandas processuais que, consequentemente, poupará dispêndio público para toda a instrução criminal, em decorrência da sua irrelevância, vez que o conflito será previamente resolvido mediante o consenso entre o acusador e o acusado.

A nível internacional cabe ressalva à Resolução 45/110 da Organização das Nações Unidas (ONU), denominada Regras de Tóquio, prevendo a adoção de medidas despenalizadoras ainda na fase pré-processual, conforme o item 5.1 da Resolução (ONU, 1990):

Sempre que adequado e compatível com o sistema jurídico, a polícia, o Ministério Público ou outros serviços encarregados da justiça criminal podem retirar os procedimentos contra o infrator se considerarem que não é necessário recorrer a um processo judicial com vistas à proteção da sociedade, à prevenção do crime ou à promoção do respeito pela lei ou pelos direitos das vítimas. Para a decisão sobre a adequação da retirada ou determinação dos procedimentos deve-se desenvolver um conjunto de critérios estabelecidos dentro de cada sistema legal. Para infrações menores, o promotor pode impor medidas não privativas de liberdade, se apropriado.

Visível é que o mecanismo internacional prevê medidas não privativas de liberdade sem desconsiderar a singularidade de cada Estado e, embora tenha caráter de soft law, ou seja, norma não obrigatória de relevante saber jurídico, o Brasil ao incorporar o acordo de não persecução, abraça a Resolução 45/110 da ONU, vez que se utiliza de método alternativo à privação da liberdade.

A fase pré-processual penal brasileira, considerada por Lopes Júnior (2020) de fase inquisitorial, encerra-se com a conclusão do inquérito policial (IP), mediante relatório feito pelo Delegado de Polícia, que terá encaminhamento ao órgão ministerial para adotar a medida que achar cabível, sendo ela optar pelo arquivamento do feito; solicitar novas diligencias junto à autoridade policial, para complementação das investigações; ou oferecer a denúncia, em caso de satisfação do IP, por garantir indícios suficientes de autoria e materialidade do fato delituoso para que o Ministério Público (MP) possa peticionar e dar início à ação penal.

A lei 13.964/19 possibilita ao MP propor também o ANPP, tornando-se uma quarta possibilidade à adoção das medidas anteriormente mencionadas, sendo adotado logo após o recebimento do IP e antes da instauração do processo penal. De acordo com o caput do artigo 28-A do CPP (BRASIL, 1941), após a conclusão do IP, não sendo caso de arquivamento, pois assim não se tem a perda do objeto, contudo, antes do ofere- 
cimento da denúncia, evitando a instauração do processo, o parquet poderá oferecer acordo não persecutório. Sua propositura poderá ser em qualquer delito, desde que com ausência de violência ou grave ameaça, inclusive cabendo para delitos que envolvam a Administração Pública e em se tratando da seara eleitoral. Além disso, estabelece que a pena mínima para o delito cometido, seja inferior a 4 anos, para que coincida com o limite aplicado às penas diversas da privativa de liberdade, podendo ainda sofrer redução de $1 / 3$ a $2 / 3$, estabelecida no ato da negociação, além disso, no quantum mencionado, considera-se as causas de aumento e diminuição da pena.

É forçoso destacar a seletividade ocasionada pelo acordo, pois ao ser implementado seleciona os casos que passarão pelo trâmite tradicional do devido processo legal, dos casos que poderão se submeter ao método desburocratizado do negócio jurídico. Contudo, a destinação primordial do pacto penal interpartes é satisfazer as finalidades do direito penal, são elas a reprovação e a prevenção dos crimes, assim, independentemente do uso de medidas privativas da liberdade, o que se torna mais relevante é a efetividade da ressocialização, sendo necessário e suficiente para tanto, atentando a proporcionalidade.

Portanto, o caput do artigo 28-A, traz requisitos cumulativos à existência do acordo, a ausência de um gera impossibilidade da realização consensual para pacificação do problema, em síntese são: não ser caso de arquivamento; o investigado deverá confessar o crime formal e circunstancialmente; o delito cometido deverá ter a ausência de violência e grave ameaça; o delito deverá ter pena mínima inferior a 4 anos; e o ANPP deverá ser necessário e suficiente à reprovação e prevenção do crime. Depreende-se, no entanto, curiosidade quanto a confissão, expressamente prevista e como requisito cumulativo, onde a sua inexistência ocasiona a perda da possibilidade de negociar na seara penal, denotando essência ao dispositivo legal.

Os incisos do caput do artigo 28-A do CPP, estabelecem as condições que poderão ser impostas no acordo, condições estas com teor alternativo (podendo escolher uma ou outra) ou com teor cumulativo (podendo adotar duas ou mais condições), são elas:

I - reparar o dano ou restituir a coisa à vítima, exceto na impossibilidade de fazê-lo;

II - renunciar voluntariamente a bens e direitos indicados pelo Ministério Público como instrumentos, produto ou proveito do crime; III - prestar serviço à comunidade ou a entidades públicas por período correspondente à pena mínima cominada ao delito diminuída de um a dois terços, em local a ser indicado pelo juízo da execução, na forma do art. 46 do Decreto-Lei no 2.848 , de 7 de dezembro de 
1940 (Código Penal);

IV - pagar prestação pecuniária, a ser estipulada nos termos do art. 45 do Decreto-Lei ${ }^{\circ}$ 2.848, de 7 de dezembro de 1940 (Código Penal), a entidade pública ou de interesse social, a ser indicada pelo juízo da execução, que tenha, preferencialmente, como função proteger bens jurídicos iguais ou semelhantes aos aparentemente lesados pelo delito; ou

$\mathrm{V}$ - cumprir, por prazo determinado, outra condição indicada pelo Ministério Público, desde que proporcional e compatível com a infração penal imputada. (BRASIL, 1941).

O inciso $\mathrm{V}$ apresenta a qualidade de rol discricionário das condições elencadas para o acordo não persecutório, podendo o MP estipular outra condição, por prazo determinado, desde que atente à proporcionalidade, averiguada no casuístico. Ainda, do mesmo inciso, decorre o encargo do MP em reduzir de 1/3 a 2/3, no ato negocial, muito embora seja competência da Vara de Execução Penal a aplicação de tal medida.

Trata-se de procedimento e não processo, haja vista não ter a presença da denúncia, dando início à ação penal, e consequentemente ser de cunho investigatório administrativo, sem a figura clássica do juiz, réu e promotor. Não implica dizer em total ausência dos três atores principais do processo penal, porém, trata-se de atribuição nova a cada um deles, considerando a formação da justiça consensual, onde todos cooperam à medida de suas capacidades, cedendo direitos em troca de outros direitos.

Ocorre que, após as deliberações entre promotor e indiciado (diferentemente de réu, qualidade esta atribuída quando há o processo), o acordo deverá ser homologado pelo juiz competente, que deverá analisar a voluntariedade e a legalidade. Além disso, incidirá sobre os processos em curso, quando da vigência da lei 13.964/19, visto que é benéfico ao réu, retroagindo ao fato, conforme artigo $5^{\circ}$, inciso XL, da Constituição da República. Ao final, para que seja fiscalizado o cumprimento do negócio jurídico, o Juízo da Vara das Execuções Penais é quem terá a competência respectiva, dando início a partir da entrega do contrato por parte do órgão ministerial.

\section{A JUSTIÇA CONSENSUAL FRENTE À INCONSTITUCIONALIDADE MATERIAL DA CONFISSÃO}

Com a nova previsão legislativa do ANPP, notória é a sua incidência em mais de $70 \%$ dos crimes penais, aumentando o arcabouço jurídico quanto à justiça negociada, indo além do que existe na lei 9.099/95 ou no negócio jurídico referente à colaboração 
premiada. Porém, o requisito da confissão formal e circunstancial é algo que vem causando incômodo no momento da aplicação do acordo de não persecução penal, vez que denota desnecessidade e consequente inconstitucionalidade material.

Os acordos em âmbitos penais, tais como a transação penal e a suspensão condicional do processo, já sofriam duras críticas quanto ao seu caráter de contrato adesivo, por findar com imposição unilateral da vontade, restando ao possível beneficiário a aceitação dos termos preexistentes e formalizados, o que é oposto à cultura da justiça consensual. No entanto, agrega-se a tal estrutura de críticas e divergências, a confissão como requisito para que o acordo não persecutório seja devidamente homologado pelo juízo competente.

O consenso jurídico penal, embora trate de relativizar direitos e garantias fundamentais, não há de se falar em ofensa ao Estado Democrático de Direito, vez que tal relativização está cedendo lugar a outros direitos e garantias, observando a necessidade do caso concreto. O parquet se absterá de promover a ação penal pública, a qual é titular, tendo em vista que é atribuição privativa do órgão, delegada pela Constituição, conforme artigo 129, inciso I, da Constituição da República, fracionando, inclusive, a obrigatoriedade da ação penal em prol do princípio da oportunidade, dando leve grau de disponibilidade à ação.

Entretanto, a confissão, como requisito para barganha entre órgão acusador e o sujeito acusado, prejudica o direito ao silêncio, previsto no artigo $5^{\circ}$, LXIII, da Constituição da República (1988), assegurando ao preso o direito de permanecer calado com a devida assistência familiar e de defesa técnica. $\mathrm{O}$ mencionado dispositivo tem suas origens na Convenção Americana de Direitos Humanos e possui a regra do nemo tenetur se detergere, assim, ninguém será obrigado a depor contra si produzindo provas, evitando a autoincriminação. Cumpre ressaltar a colisão com direito constitucionalmente previsto, em seu aspecto material.

Outro aspecto material da Constituição violado, que pode ser notadamente argumentado, refere-se ao princípio da Dignidade Humana, contido no artigo $1^{\circ}$, inciso III, da Constituição da República, pois, sendo ele a base de todo o Estado Democrático de Direito, tratando os indivíduos como sujeitos de direito dentro do âmbito persecutório penal, não mais como objeto, a confissão como cessão necessária por parte do indiciado apresenta-se como fundamento à instauração da ação penal, tornando-se verdade real, por assim dizer, finda por tornar objeto o indivíduo, servindo apenas aos caprichos do ius puniendi.

Contudo, embora o acusado possa optar em aceitar ou não o negócio (requisito da voluntariedade, analisado no momento da homologação), estará o mesmo adstrito às imposições contraídas no acordo que, ao aceitá-las, estará automaticamente confessan- 
do o delito, podendo fazê-lo não só por questões de ser de fato o autor do crime, mas pelos benefícios que se angaria ao momento do oferecimento do ato formal não persecutório, tal como a não formação de antecedentes criminais, para fins de reincidência, ou o fato de não haver punição com pena privativa de liberdade.

A confissão, por sua vez, não é averiguada no momento da ratificação judicial, pois seria entrar no mérito da causa e ao homologar o acordo, o Judiciário apenas analisa as condições de legalidade e voluntariedade, reafirmando a necessária dispensa da confissão em fase pré-processual, a nível de ANPP, já que é trabalhada em fase processual, a título de mérito, demonstrando ferimento ao artigo $8^{\circ}$, $2^{\circ}$, da Convenção Americana de direitos Humanos, recepcionada pela Constituição Federal brasileira, ao trazer o devido processo legal como forma devida de averiguação de culpa, consequentemente preservando também a presunção da inocência.

A Declaração Universal de Direitos Humanos aprovada pela ONU, em seu artigo 11 afirma:

Todo ser humano acusado de um ato delituoso tem o direito de ser presumido inocente até que a sua culpabilidade tenha sido provada de acordo com a lei, em julgamento público no qual lhe tenham sido asseguradas todas as garantias necessárias à sua defesa.

A formalização do acordo, necessariamente se dá por escrito, devendo conter não somente a presença do MP e acusado, mas também da defesa técnica para a efetividade do contraditório e ampla defesa. Embora devidamente acompanhado, as reais consequências jurídicas são perceptíveis no momento da confissão, em que o acusado declara culpa, ferindo o princípio constitucional da presunção da inocência, antecipando a culpa ao período pré-processual, desconsiderando a sua averiguação mediante o devido processo legal, com a sentença transitada em julgado.

A eficácia de uma norma jurídica necessita estar de acordo com alguns requisitos, destacando-se entre eles a existência de possível vício na sua origem que caso seja confirmado irá gerar uma inconstitucionalidade formal ou material. A diferença entre ambos se dá no local do vício, pois enquanto o primeiro é notado em sua origem, o segundo a inconstitucionalidade ocorre na matéria da lei, ou seja, na essência da lei.

O vício formal ocorre quando em algum momento do trâmite legal há uma violação aos pressupostos e do procedimento solene, ou seja, ocorreu uma transgressão a guisa na formação da lei, o vício nesses casos, ocorrem no ato dos pressupostos, no procedimento de formação ou na sua forma final (Mendes, 2018).

$\mathrm{O}$ vício material acontece na medida que a lei se torna incompatível, através de uma 
violação ao integrado na Lex Legum ou então a algum princípio fundamental protegido por ela. Axiomático o encaixe da inconstitucionalidade material no âmbito do ANPP, uma vez que um de seus requisitos para sua validade é a confissão do indiciado, medida notoriamente contrária a presunção da inocência aderida pela Carta Magna.

Esse princípio é um norteador do direito brasileiro, pois através dele há uma cisão dos excessos do Estado com o cidadão, possibilitando uma busca pela verdade sem a violação dos preceitos fundamentais. O Brasil por acolher o sistema misto na sua persecução penal apenas reforça o quão necessário é este princípio para realização da justiça, demonstrando assim uma arbitrariedade do legislador ao prever a confissão como condição com o intuito de garantir um benefício para as partes.

Demonstrada a abusividade quando se nota o quão é desnecessário a confissão no ANPP, uma vez que a finalidade de tal instrumento é a agilidade processual para crimes pequenos somado a intenção de uma ressocialização do delinquente, fatos independentes da necessidade da manifestação compulsória do acusado.

A justiça negocial caracteriza-se por um acordo justo entre as partes visando uma substituição da pena, notada a eficácia prática na transação penal e na suspensão condicional do processo executada nos Juizados Especiais Criminais que não tem a confissão como indispensável para sua oferta, logo, malgrado o ANPP ter como destaque os requisitos de uma negociação judicial ela se evidência por possuir uma inconstitucionalidade material, violadora de um princípio ponderoso no ordenamento jurídico desnecessariamente, afinal a confissão não é critério para validade de um acordo jurídico.

Cumpre ressaltar que a confissão como requisito, assemelha-se com a rainha das provas, potencializando a busca incessante da verdade real às custas da desjudicialização dos atos, entretanto, na confissão em si, o acusado reconhece os fatos, sem, no entanto, ter ciência plena das consequências jurídicas. Ao confessar o delito, está se admitindo culpa, o que vai além do reconhecimento do casuístico, porém, na justiça consensual, essa autoacusação não é essencial, sendo necessária apenas a convenção interpartes.

Ainda, ocasionará disparidade entre os integrantes do procedimento, pois a acusação possuirá maior vantagem sobre o acordo, que uma vez extinto por qualquer motivo, que não por cumprimento integral do negócio jurídico, o membro do Ministério Público deverá oferecer a denúncia de imediato, com a finalidade de instauração do processo penal, podendo se utilizar da confissão como embasamento ao seu pleito, como consequência jurídica, de certo modo, não visualizada em primeira mão, se tem a não possibilidade de celebrar suspensão condicional do processo, embora não incida a sanção em forma de astreintes, para o descumprimento, a imediata instauração da ação penal corresponde a tal punição possuindo efeitos jurídicos bem maiores que o mero pagamento da multa, considerando a vantagem do órgão acusador pela obtenção de tal requisito, muitas vezes 
impensado, devidamente analisado apenas com um processo instrutório.

O que denota agravamento à situação ora analisada, é a suspensão do denominado juiz das garantias, mediante liminar, situado no artigo $3^{\circ}$-B do CPP, pois seria o responsável pela homologação do procedimento do negócio de não persecução penal, com vistas a julgar eventual ilegalidade ou coação para obrigar o acusado a aceitar o acordo, diferentemente do juiz responsável pela instrução criminal, que tratará do mérito, onde só então poderá trabalhar a confissão.

Sem a figura do juiz das garantias, consequentemente o magistrado que analisa o ANPP será o mesmo de eventual instrução, em caso de o parquet oferecer a denúncia pelo não cumprimento do instituto aplicado ao acusado. A distinção de atribuições reforça a ideia de, no ato da homologação do acordo, ser examinado unicamente a voluntariedade e a legalidade do ato, tendo em vista o disposto no artigo $28-\mathrm{A} \S 6^{\circ}$, do CPP, quanto à monitoração do acusado ao cumprimento efetivo do negócio, ser de competência da Vara da Execução Penal.

\section{CONSIDERAÇÕES FINAIS}

O acordo de não persecução penal é instituto inovador no âmbito jurídico brasileiro, principalmente por enriquecer o setor penal com nova forma para dirimir conflitos, ainda mais em uma área que pouco possibilita a disponibilidade de direitos. Muito embora prometa satisfazer os anseios sociais, de ver punir os infratores e resguardar a boa reputação do Poder Judiciário, um impasse pode ser observado quando da feitura do ANPP, sendo ele quanto à confissão, expressamente contida no caput do artigo 28-A do CPP, com a qualidade de cumulativo aos demais requisitos, tornando-se essencial e indispensável à feitura do mencionado negócio jurídico.

Contudo, a confissão denota irrelevância para constituição da barganha, tendo em vista se tratar de contrato consensual e como tal a necessidade maior se faz no momento do acordo de vontades, devidamente pactuadas, quanto a determinadas questões imputadas ao acusado. Além disso, visível é a possível forma de contrato de adesão, restando ao indiciado aceitar o que lhes foi unilateralmente oferecido.

No ato de homologação do acordo, o magistrado deverá, unicamente, averiguar a voluntariedade, para impedir eventual coação em prol da realização não consentida do acordo, bem como a legalidade do referido contrato. Assim, eventuais problemas referentes à confissão serão analisados no bojo de processo penal, mediante fase instrutória, reforçando a ideia falida do requisito logo em momento inicial para formalização do pacto interpartes.

As efetivas consequências do acordo somente poderão ser notadas ao longo do tem- 
po, dado o seu teor inovador, requerendo aplicação. Então, a confissão e seus possíveis efeitos, somente poderá apresentar maior incomodo e demandar atenção, à medida de sua utilização diária. Entretanto, sua propositura como está, poderá angariar prejuízos, principalmente ao acusado que precisa admitir culpa, objetivando adquirir benevolência estatal. Portanto, a confissão como requisito essencial à homologação do acordo pelo Judiciário não possui utilidade constituída de forma legal.

\title{
MATERIAL UNCONSTITUTIONALITY OF CONFESSION IN THE CRIMINAL NON-PERSECUTION AGREEMENT
}

\begin{abstract}
The non-criminal prosecution agreement was dependent on the criminal procedure code through Law 13964/19, with the aim of improving the negotiated justice and favoring the fulfillment of demands in order to generate more effective punishment. However, a problem took over, namely confession as a requirement for the conclusion of the agreement between the Public Prosecutor and the accused, which denotes unconstitutionality for this purpose, in view of its notorious needlessness, gaining an advantage to the parquet in possible prosecution. Starting from the bibliographic and documentary method, the present work will present how the unconstitutionality of the material confession occurs, starting from the analysis of the historical evolution of the criminal process to the insertion of the agreement in the Brazilian legal scope, in order to show the addiction without the requirement of confession. So, although it is an innovative institute, the discussion is valid, considering that it will cause practical legal effects over time.
\end{abstract}

Keywords: Confession. Public Ministry. Non-Persecution Agreement. Consensual Justice.

\section{REFERÊNCIAS}

BRASIL. Constituição da República Federativa do Brasil de 1988. Disponível em: http://www.planalto.gov.br/ccivil_03/constituicao/constituicao.htm. Acesso em: 07 mar. 2020.

BRASIL. Decreto-lei $\mathbf{n}^{0}$ 3.689, de 3 de outubro de 1941. Código de Processo Penal. Disponível em: http://www.planalto.gov.br/ccivil_03/decreto-lei/del3689compilado- 
htm. Acesso em: 11 mar. 2020.

BRASIL. Lei no 9.099, de 26 de setembro de 1995. Dispõe sobre os Juizados Especiais Cíveis e Criminais e dá outras providências. Disponível em: http://www.planalto.gov. br/ccivil_03/leis/19099.htm\#: :text=LEI\%20N\%C2\%BA\%209.099\%2C\%20DE\%20 26\%20DE\%20SETEMBRO\%20DE\%201995.\&text=Disp\%C3\%B5e\%20sobre\%20 os \%20Juizados\%20Especiais\%20C\%C3\%ADveis\%20e \%20Criminais\%20e\%20 d\%C3\%A1\%20outras\%20provid\%C3\%AAncias. Acesso em: 11 mar. 2020.

BRASIL. Lei $\mathbf{n}^{\mathbf{0}}$ 13.964, de 24 de dezembro de 2019. Aperfeiçoa a legislação penal e processual penal. Disponível em: http://www.planalto.gov.br/ccivil_03/_ato20192022/2019/lei/L13964.htm. Acesso em: 2 abr. 2020.

CNJ. Regras de Tóquio: Regras Mínimas Padrão das Nações Unidas para a Elaboração de Medidas não Privativas de Liberdade. CNJ, 2016: Disponível em: https://www. cnj.jus.br/wp-content/uploads/2019/09/6ab7922434499259ffca0729122b2d38-2.pdf. Acesso em: 10 abr. 2020.

CUNHA, R. S. et al. (coord.). Acordo de Não Persecução Penal: Resolução 181/2017 do CNMP com alterações feitas pela Resol. 183/2018. 3. ed. rev., amp. e atual. Salvador: JusPodivm, 2020.

DECLARAÇÃO UNIVERSAL DOS DIREITOS HUMANOS. Brasa, 2013. Disponível em: https://brasa.org.br/declaracao-universal-dos-direitos-humanos/?gclid=Cj0KC Qjw8fr7BRDSARIsAK0Qqr7KX0jnkgcz87ydjchR_oYyb8Yb5K3T-T9j17u8dzh1sfavoYBxLIAaAs56EALw_wcB. Acesso em: 05 out. 2020.

LIMA, R. B. Manual de Processo Penal. 5. ed. rev., amp. e atual. Salvador: JusPodivm, 2017.

LOPES JÚNIOR, A. Direito Processual Penal. 17. ed. São Paulo: Saraiva, 2020.

SÁNCHEZ, J. M. La Expansión desl Derecho Penal: Aspectos de la política criminal en las sociedades postindustriales. 2. ed. rev. e amp. Madrid: Civitas, 2001

TÁvorA, N. Curso de Direito Processual Penal. 14. ed. Salvador: JusPodivm, 2019. MENDES, G. F.; BRANCO, P. G. G. Curso de Direito Constitucional. 13. ed. São Paulo: Saraiva, 2018. 